\title{
The Conceptual Framework of Entrepreneurial Determinants and Entrepreneurial Intention Among Universiti Teknologi Malaysia Undergraduate Students
}

Sabrinah Adam, Ng Jing Wen, Nursyazwani Mohd Fuzi and Mohd Khairuddin Ramliy

To Link this Article: http://dx.doi.org/10.6007/IJARBSS/v11-i2/8894

DOI:10.6007/IJARBSS/v11-i2/8894

Received: 18 December 2020, Revised: 09 January 2021, Accepted: 19 January 2021

Published Online: 14 February 2021

In-Text Citation: (Adam et al., 2021)

To Cite this Article: Adam, S., Wen, N. J., Fuzi, N. M., \& Ramliy, M. K. (2021). The Conceptual Framework of Entrepreneurial Determinants and Entrepreneurial Intention Among Universiti Teknologi Malaysia Undergraduate Students. International Journal of Academic Research in Business and Social Sciences, $11(2), 825-831$.

\section{Copyright: (c) 2021 The Author(s)}

Published by Human Resource Management Academic Research Society (www.hrmars.com)

This article is published under the Creative Commons Attribution (CC BY 4.0) license. Anyone may reproduce, distribute, translate and create derivative works of this article (for both commercial and non-commercial purposes), subject to full attribution to the original publication and authors. The full terms of this license may be seen at: http://creativecommons.org/licences/by/4.0/legalcode

Vol. 11, No. 2, 2021, Pg. 825 - 831 


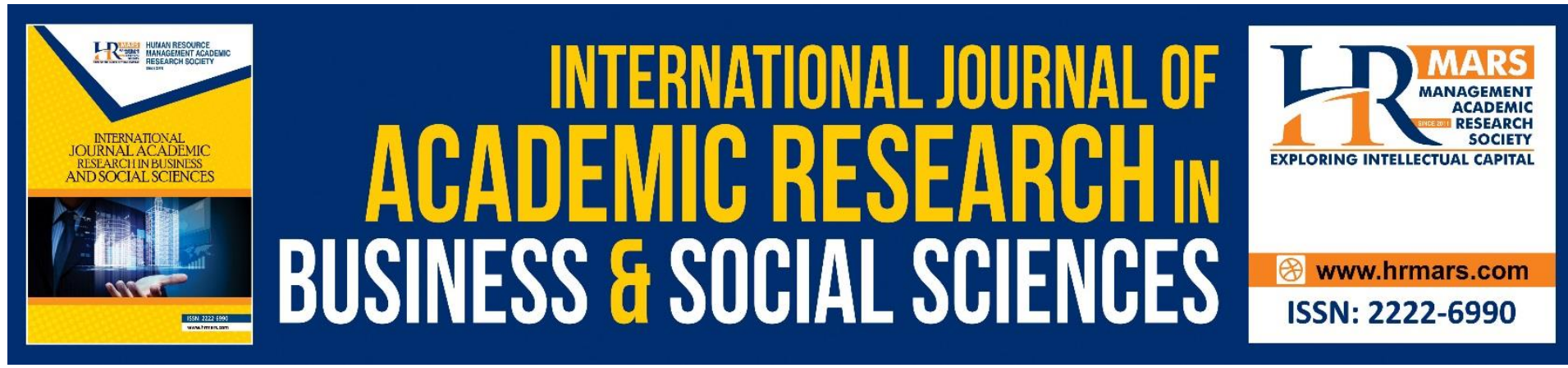

\title{
The Conceptual Framework of Entrepreneurial Determinants and Entrepreneurial Intention Among Universiti Teknologi Malaysia Undergraduate Students
}

\author{
Sabrinah Adam, Ng Jing Wen, Nursyazwani Mohd Fuzi and \\ Mohd Khairuddin Ramliy \\ Azman Hashim International Business School, Universiti Teknologi Malaysia, 81310 Skudai, \\ Johor, Malaysia \\ Email: sabrinah@utm.my
}

\begin{abstract}
The aim of this conceptual paper is to review the relationship between entrepreneurial determinants and entrepreneurial intention among undergraduate students of Universiti Teknologi Malaysia (UTM). The variables consist of entrepreneurial attitude (EA), subjective norms (SN), perceived behavioral control (PBC) and entrepreneurship education (EE) as independent variable and entrepreneurial intention (EI) is the dependent variable. This study adopted quantitative approach using IBM SPSS version 26 . The survey was conducted on undergraduate students Universiti Teknologi Malaysia. The conceptual framework has been developed in this study. The conceptual framework developed in this study can be used as a guideline to implement the entrepreneurial determinants and entrepreneurial intention among undergraduate students of Universiti Teknologi Malaysia. Thus, a conceptual framework of the importance of entrepreneurial determinants and entrepreneurial intention, can serve to guide future research.
\end{abstract}

Keywords: Entrepreneurial Attitude, Subjective Norms, Perceived Behavioral Control, Entrepreneurship Education and Entrepreneurial Intention

\section{Introduction}

Entrepreneurship plays a critical role in generating economic growth and social stability among all the countries. The development of entrepreneurship causes more job creations with the purpose of wealth creation and standard living improvement as well as addressing unemployment issues by providing new job opportunities (Mwasalwiba, 2010). Besides, entrepreneurship also fulfils the need of self-achievement among individuals with creative propensity and risk-taking propensity (Shah et al., 2020) through undertaking innovative business.

By recognizing the importance of developing entrepreneurship, government strived to implement policies that enable to boost entrepreneurship among nations. One of the initiatives was investing in entrepreneurship educaation. According to the research 
conducted by Byrne et al. (2014), school was found to be an appropriate place to discover the potential of student to startup a business and enhance their entrepreneurial skills. As a result, entrepreneurship education was promoted to nationwide for so many years in order to create a community with entrepreneurial mindset, skills and behavior (Ayuo et al., 2017).

Given the important role in nurturing and creating more future entrepreneurs, Malaysia government had also implemented several policies. Malaysia National Higher Education Action Plan 2007-2010 was one of the policies that aims to embed entrepreneurial mindset and skills among students in higher education institutes (HEI) through the entrepreneurship education (Utami, 2017). The purpose of establishing the government policy related to entrepreneurship development was to encourage and enhance the entrepreneurship development in a more systematic and holistic way among local universities in Malaysia according to Dasar Pembangunan Keusahawan (2017).

In order to raise the awareness among university students, an entrepreneurship education program named as Modul Asas Pembudayaan Keusahawan (APK) was introduced in 2007 (Dasar Pembangunan Keusahawaan, 2017). Ministry of Higher Education Malaysia had taken the initiative by making entrepreneurship as a compulsory subject to all undergraduate students at the nation public universities with the hope of embedding the students' entrepreneurial attitudes and mindset in the nation's drive to develop entrepreneurs from the local graduates since 2007 (Wahidmurni et al., 2020). With this initiative, government aims to build more human capital especially from the students in university level to instill entrepreneurial attribute and values with the hope of creating more entrepreneurs who will act as the catalyst to boost the economic growth and social development through innovation (Dasar Pembangunan Keusahawaan, 2017).

The following section will discuss on the development of conceptual framework between entrepreneurial determinants (entrepreneurial attitude, subjective norms, perceived behavioral control and entrepreneurship education) and entrepreneurial intention among undergraduate students of Universiti Teknologi Malaysia (UTM). Next sections, followed by a brief discussion of the research methods. Finally, this paper end with a conclusion of the present study.

\section{Literature Review}

\section{Entrepreneurial Determinants}

A recent study conducted by Wahidmurni et al. (2020) was to analyze the main factors that could predict entrepreneurial intention of university students and twenty articles of research carried out in 19 countries and 5 continents that 117 research hypotheses were tested were the main data source of this research. The results indicated that the internal factors such as three antecedents developed from Theory of Planned Behavior (TPB) which are entrepreneurial attitude, subjective norms and perceived behavioral control tended to be more considered in predicting entrepreneurial intentions, while the external factors such as entrepreneurship education is also meaningful in shaping entrepreneurial intention.

The entrepreneurial determinants consist of entrepreneurial attitude (EA), subjective norms (SN), perceived behavioral control (PBC) and entrepreneurship education (EE). EA refers to a person tendency to initiate entrepreneurship if he perceived that starting a business is favorable, valuable and beneficial. According to Volery et al. (2013), entrepreneurial intention can be motivated by personal belief that an individual who desire to become an entrepreneur. Hence, entrepreneurial attitude decides the desirability of a person to perform entrepreneurial behavior. 
$\mathrm{SN}$ are the perception of a person on how social pressure affect his decision to perform such behavior (Ajzen, 1991). Hence, subjective norms are a factor that using social influence to give impact on a person whether to pursue his entrepreneurial intention and turn it into real behavior. Krithika and Venkatachalam (2014) found that subjective norm played an important role in influencing the entrepreneurial intentions among students. It is expected that a person tends to carry out entrepreneurial activity if he gained support from 'role model' or 'mentor' or received higher expectation from the people who think he will succeed in undertaking innovative business.

PBC refers to the perception of a person about his ability or feasibility to execute a behavior (Ajzen, 1991). In this context, it means that a person will evaluate to what extent his theoretical and empirical background can assist him to start up a new business. PBC is also termed as perceived self-efficacy which corresponds to individual's belief or self-assessed ability to successfully execute behavior (Ajzen, 1991). Previous study found that PBC was the most significant variable that was proved to perfectly influence entrepreneurial intention of university students (Wahidmurni et al., 2020.) A person who thinks he has high self-efficacy is more feasible to drive the intention to act as an entrepreneur.

EE was defined as an educational process that can influence individual attitude, intention and behavior to acquire entrepreneurial skills which related to new business formation by recognizing market opportunities (Mwasalwiba, 2010). Hernandez-Sanchez, Sanchez-García and Mayens (2019) summarized that problem solving skills and managerial skills for planning and decision making, social competencies for networking and cooperating, personal competencies such as self-confidence and critical thinking as well as entrepreneurial skills such as creativity, proactivity and risk taking are all the substantial learning outcomes through the entrepreneurial education. In this study, entrepreneurial education refers to the learning process of acquiring theoretical knowledge and practical skills with the purpose of enhancing students' competencies to start a new business.

\section{Entrepreneurial Intention (EI)}

Intention was described as the motivational factors affecting someone's behavior (Azjen, 1991) while entrepreneur is a person who undertakes and operates a new business with certain risks Stevenson and Jarillo (1990). El was referred as "self-acknowledged conviction that bring a person tendency to start a new business venture and plan to do so consciously at some point in the future" (Thompson, 2009). Hence, entrepreneurial intention could be referred to a person tendency in planning to venture into a new business startup if there is a chance to do so. A person who had strong intention will show great interest and desire to carry out an action that he wanted to achieve.

El was evaluated instead of entrepreneurial behavior as Shen et al. (2010) stated that time lag effect to study the entrepreneurial rate from receiving entrepreneurship education to actual business startup made researchers found difficulty in evaluating real entrepreneurial behavior. Study on $\mathrm{El}$ is able to recognize the determinants that driving undergraduates' intention toward entrepreneurship (Stevenson \& Jarillo, 1990). Since entrepreneurial intention is a crucial variable to foster prospective entrepreneurs, many researches were conducted to find out the influencing factors of entrepreneurial intention

\section{Research Methodology}

A quantitative survey method is used to carry out the study. Descriptive research was used to draw a conclusion on the students' entrepreneurial intention based on different 
entrepreneurial determinants by collecting and analysing data from targeted respondents from the population. The population in this study was undergraduate students who studying in Universiti Teknologi Malaysia (UTM), Johor Bahru in the academic year 2020/2021. Total of 350 respondents were selected to obtain a reliable data with 95 percent confidence level and \pm 5 percent allowable error. Random sampling method was applied to select the respondents of the study. Hence, all the undergraduate students in UTM have an equal chance to be selected as the respondents of the study.

The data will be analysed using the Statistical Package for the Social Sciences (SPSS) version 26 to evaluate the purchase intention among UTM undergraduate students. Numerous data analysis sets will be used in this study such as analysis on reliability, descriptive analysis, t-test, one-way ANOVA, analysis of multicollinearity, and analysis of multiple regressions.

\section{A Proposed Conceptual Model}

Ajzen's Theory of Planned Behavior (1991) illustrated a model adopted in an intentional behavior. TPB is applied as an intentional based model to predict entrepreneurial behavior. Within the context of entrepreneurial intention, the behavioral intentions are influenced by three antecedents which are entrepreneurial attitude, subjective norms and perceived behavioral control.

TPB theory was adopted since it is able to explain human intention towards a behavior. TPB not only can be applied in psychology field but numerous studies also adopt this theory to study entrepreneurial intention the similar research in entrepreneurship context. For example, Maresch et al. (2016) studied the effect of entrepreneurship education on the entrepreneurial intention between science and engineering and business students in university in Netherland using the three antecedents of TPB and the finding revealed that TPB was generally effective for El. Besides, Utami (2017) also studied three antecedents of TPB, entrepreneurship education and self-efficacy toward entrepreneurial intention by collecting data from 1237 students from academic year 2012-2015 in university in Indonesia. Another two research among university students in Turkey and Oman also found that three antecedents of TPB established a positive and significant effect on entrepreneurial intention (Izedonmi \& Okafor ,2010; Shah, Amjed, \& Jaboob, 2020).

Entrepreneurial determinants were the independent variables whereas entrepreneurial intention was the dependent variable of this study. The entrepreneurial determinants were entrepreneurial attitude, subjective norms and perceived behavioral control from Theory of Planned Behavior (TPB) with entrepreneurship education. The proposed conceptual framework of this study was summarized as per shown in Figure 1. 


\section{Entrepreneurial Determinants}

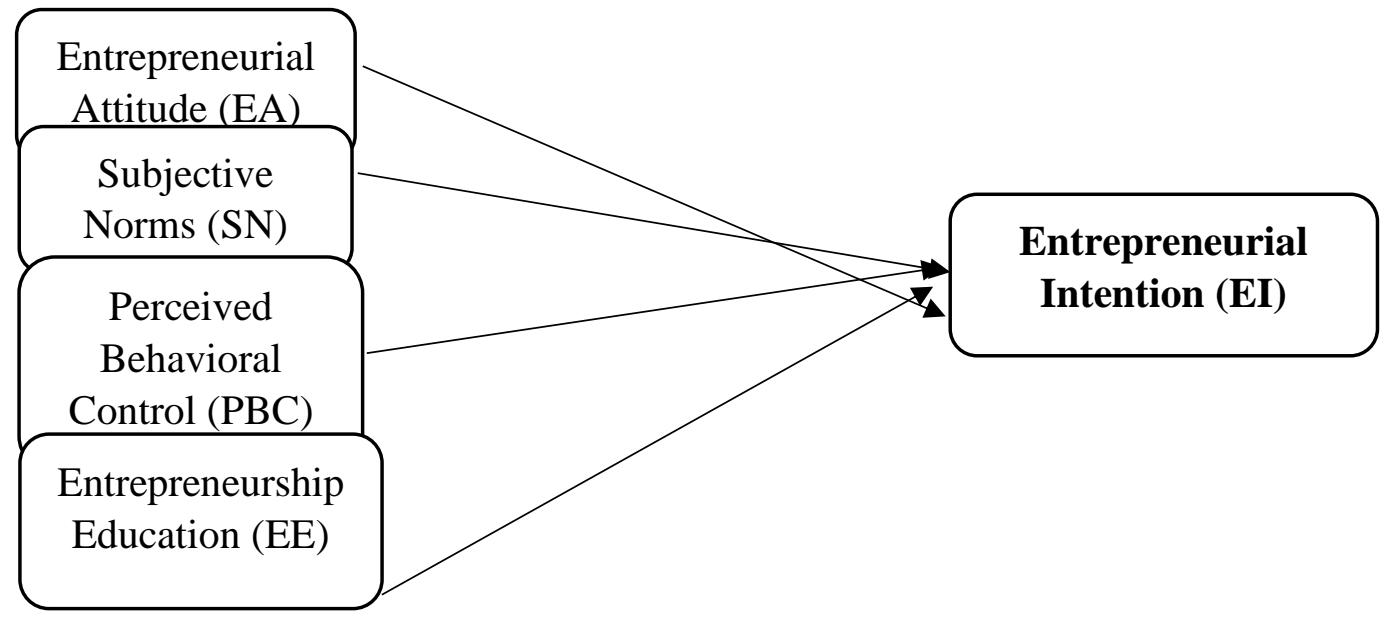

Figure 1. The Proposed Conceptual Model

\section{Conclusion}

This study provides an insight about the entrepreneurial intention among undergraduate students in UTM and enhance the understanding of factors that bring more significant influences on students' entrepreneurial intentions. Therefore, this investigation is expected to contribute to further studies in entrepreneurship field.

It is suggested that the similar research can be conducted in few other universities in Malaysia by expanding the sample size to collect a more collective database that help other scholars or policy makers to redesign and restructure a more holistic entrepreneurship education program which suit to enhance students' entrepreneurial intention in overall effect. Since the influence of entrepreneurship education towards entrepreneurial intention still considered low, the barriers and suggested solutions in promoting students' entrepreneurial intention are recommended for further study. Educators and policymakers who wish to promote entrepreneurial intentions among students can improve the course content and pedagogy approach through solving the issues and challenges faced during delivering the entrepreneurship education.

\section{References}

Ajzen, I. (1991). Theory of planned behavior. Organizational Behavior and Human Decision Processes, 50, 179-211.

Ayuo, A. O., Auka, D., \& Kibas, P. (2017). Entrepreneurship Education, Attitudes and Entrepreneurial Intention of Engineering Students in Technical and Vocational Education and Training Institutions in Kenya. European Journal of Business and Management, 9(33), 85-98.

Hernandez-Sanchez, B. R., Sanchez-Garcia, J. C., \& Mayens, A. W. (2019). Impact of entrepreneurial education programs on total entrepreneurial activity: The case of Spain. Administrative Sciences, 9(1), 25.

Izedonmi, P. F., \& Okafor, C. (2010). The effect of entrepreneurship education on students' entrepreneurial intentions. Global Journal Of Management And Business Research, 10(6), 79-93. 
Krithika, J., \& Venkatachalam, B. (2014). A study on impact of subjective norms on entrepreneurial intention among the business students in Bangalore. IOSR Journal of Business and Management, 16(5), 48-50.

Maresch, D., Harms, R., Kailer, N., \& Wimmer-Wurm, B. (2016). The impact of entrepreneurship education on the entrepreneurial intention of students in science and engineering versus business studies university programs. Technological Forecasting And Social Change, 104, 172-179.

Mwasalwiba, E. S. (2010). Entrepreneurship education: a review of its objectives, teaching methods, and impact indicators. Education+ Training, 52(1), 20-47.

Shah, I. A., Amjed, S., \& Jaboob, S. (2020). The moderating role of entrepreneurship education in shaping entrepreneurial intentions. Journal of Economic Structures, 9(1), 1-15.

Shen, C., Chen, B., \& Chen, H. (2010). "Time lag effect" and evaluation of entrepreneurial education effect in entrepreneurship education. Innovation and Entrepreneurship Education, 1(4), 3-7.

Stevenson, H. H., \& Jarillo, J. C. (1990). A Paradigm of Entrepreneurship: Bibliography 225 Entrepreneurial Management. Strategic Management Journal, 11, 17-27.

Thompson, E. R. (2009). Individual entrepreneurial intent: Construct clarification and development of an internationally reliable metric. Entrepreneurship Theory And Practice, 33(3), 669-694.

Utami, C. W. (2017). Attitude, subjective norm, perceived behaviour, entrepreneurship education and self-efficacy toward entrepreneurial intention university student in Indonesia. European Research Studies Journal, 2A, 475-495.

Volery, T., Müller, S., Oser, F., Naepflin, C., \& Rey, N. D. (2013). The impact of entrepreneurship education on human capital at upper-secondary level. Journal of Small Business Management, 51(3), 429-446.

Wahidmurni, W., Indah, A. Z., Alfiana, Y. E., \& Abdussakir, A. (2020). Entrepreneurial intention of university students and the affecting factors. Library Philosophy and Practice, 10 (4), $1-14$. 